\title{
And God Saw That It Was Bad (I viděl bůh, že je to špatné)
}

Author: Otto Weiss

First Published: 1997 (written 1943)

Translations: German (Und Gott sah, dass es schlecht war, 2002); Hebrew (Va-yar Elohim ki ra: sipur mi-gețo Ṭerezin, 2009); English (And God Saw That It Was Bad, 2010).

About the Author: Otto Weiss (1898-1944) was born in Pardubice, a town in Eastern Bohemia. Having been injured during World War I, he was not able to study the piano which had been his dream. He became a bank clerk and lived with his family in Prague. In December 1941, he was deported to the Theresienstadt Ghetto along with his wife Irena and daughter Helga. Before being transported from Theresienstadt to Auschwitz-Birkenau (1.10.1944), he managed to hand over his literary works and along with his drawings and the diary of his maturing daughter to his relative Josef Polák, who bricked these items in Theresienstadt. Weiss did not survive, unlike to the rest of his family. After the war, Polák retrieved the documents and handed them over to Weiss' daughter. Otto Weiss was a non-professional writer and an occasional poet. His literary work was mainly written in Theresienstadt. It contains, apart from this novella, several dozen poems that he collected into a volume (edited posthumously).

Further Important Publications: Tak bolely hvězdy (1998, How the Stars Were Hurting; poems).

\section{Content and Interpretation}

The plot of the story, which was written in the Theresienstadt Ghetto in 1943, is very simple. Hearing the prayers of the truly devout Vitězslav Taussig, who lived in the ghetto, God decided to go in the flesh of Aron Gottesmann in order to visit Theresienstadt personally to help him. Mr Taussig's package, which God sent answering Taussig's prayers, seemed to have gotten lost; in reality it was stolen. Although God wanted to right the wrongs, he was not able to help Taussig, in addition, He could not save himself from the transport to the East. Moreover, He was not even able to help Himself from being charged with theft and sentenced unjustly. Consequently, He decided to pretend to be terminally ill and His human alter ego died in order to get out of Theresienstadt.

His escape (sic!) back to Heaven from all the human sufferings happened during His seventh day in Theresienstadt, the biblical day of rest (Wittemann, 2004, p. 218). Significantly, He was hurrying "home" by way of the crematorium in Theresienstadt and the narrator speaks directly to the reader about the fact that God has left and returned to Heaven. "Be patient a little while longer, wait quietly, and you will soon be rewarded. And then forgive Him, please, because He didn't mean it to be like that”

Ә Open Access. (C) 2021 Štěpán Balík, published by De Gruyter. (cc) BY-NC-ND This work is licensed under a Creative Commons Attribution-NonCommercial-NoDerivatives 4.0 License. https://doi.org/10.1515/9783110671056-003 
(Weiss, 2010, p. 70). And leaves it up to the reader whether or not this was meant sarcastically.

God seemed to be a totally helpless entity. However, the sense can differ while reading the novella word by word, sarcastically or stressing the hidden hints which can be even seen as a picture of the European political insanity in the 1930s and 1940 s of the 20th century and the Nazis themselves. The war and the Shoah can be interpreted as a punishment like the biblical flooding for people's loss of faith in God and being evil to each other as it is shown in God's perspective in the very beginning: "Mankind no longer believed in Him; they bowed down other gods, and it served them right!” (p. 11) On the other hand, God's manner of thinking in the story can also recall the figures of speech and rhetorical strategies towards Jews and the public in general by the Nazis.

\footnotetext{
He had taken care of His faithful, His Chosen People, and almost to the last He had led them from the great cities and the towns and the tiny villages to deliver them from evil and the hatred that had run wild over half the globe. He had gathered them all together in a few large centres, crowded together so that they would not feel lost and lonely in the world gone mad. He had led them eastward and gathered them in a small town in the heart of Europe, where they could wait in peace for things to settle down; where they could work hard and serve Him (pp. 11-12).
}

The narrator also stressed the Jewish expectations and desperate dreams of Jewish prisoners hoping to come home. Their belief in God, by contrast, had disappeared (p. 70). However, old people were the only social group which represented the old world where there was no place for any doubts about God almighty, even though they suffered the most: "Vítězslav Taussig, Mr Pentlička, old Mr Winter and all the rest would go on believing in the face of all the trials sent to them (as they thought) by God" (p. 70).

The title of the novella is an ironic allusion to the words from Genesis (Genesis 1, 21 and 25). The story's ironic perspective is stressed by using the structure of religious fairytale like parable, which is divided into a six day rhythm (Wittemann, 2004, p. 217; cf. Badinová, 2016), that could be seen as the "narrative trick" for the author's plot (Sabin, 2002, p. 61; cf. Demetz, 2003, p. 32). Demetz also stressed a connection with the traditions of Czech literature (p. 32).

\section{Main Topics and Problems}

The hic et nunc perspective determines the writing in general. In addition, the book was originally created for only one reader. In the ghetto, the novella, illustrated by author's daughter Helga, was dedicated to the author's wife Irena for the occasion of her birthday (22nd June, 1943). Thereby, the text served as an interfamilial communication primarily, because each of them was stationed in different barracks (cf. Demetz, 2003, p. 32).

The illustrations in the typewritten original were smaller, as the author left some place for his daughter's drawings, thus, from the very beginning, the work was in- 
tended as a Gesamtkunstwerk, to a certain extent. In this way, it was analogous to Jan Munk's Theresienstadt in Bildern und Reimen (Theresienstadt in Pictures and Rhymes) or some handmade magazines produced by persecuted Jewish teens (Munk, 2004; cf. Balík, Holý, 2016, pp. 473-476) (Klepy from České Budějovice or Vedem, Kamarád, RIM RIM RIM, Domov, Bonaco from Theresienstadt).

The depiction of the Theresienstadt Ghetto was also formed by its specific language devices. Apart from specific Jewish vocabulary, (e.g. nebich = poor fellow), the most of the significant expressions came from Theresienstadt Ghetto jargon (šlojska $=$ the place where the deportees were checked and part of their belongings was confiscated or stolen, terezinka = enteritis caused by poor food condition, often fatal etc.). Some particular devices of the Weiss novella were names as signs (nomina omina) and language hints as well as plays on words. God came to the Theresienstadt Ghetto in the person of Aaron Gottesmann from Himmelblau (Blue Heaven in German) and, exceptionally in contrast to other people transported to Theresienstadt, he was an Einzelreisender (lone traveller), which connotes with God's uniqueness. The name of God itself was also often targeted by significant phrases as e.g. "God help you”. Moreover, Gottesmann went for delousing, "partly because he did not want to risk taking his lice back to Heaven with him" (Weiss, 2010, p. 56).

The narrator was also very critical of the injustice in the ghetto, the situation of elderly people and especially of the Zionists, who were in charge of the Jewish self-government including labour, youth health services and the elderly people in the ghetto (Bondy, 2010, p. 76). The author refrained from any pointed direct remarks about Nazi authorities probably because they feared for personal safety. Further on, Ruth Bondy showed other circumstances and stressed Weiss' Czech Jewish point of view, which comes out of the Austro-Hungarian and Czechoslovakian cultural and political traditions (pp. 75-76).

Criticism of the social status of elderly people, discrimination of the weak, favouritism and inhuman behaviour in the ghetto are shown very often in a very sarcastic way in the novella. An old man even claimed: "That's the saddest thing of all, that we've created our own Hell here“ (Weiss, 2010, p. 58). Such a picture of the Theresienstadt Ghetto was supported by a disgusting scene some pages afterwards. Although a nurse seemed to be gentle to the old dead Gottesmann, she grumbled with disappointment "A bachelor, by the look of him, not even a ring...” (p. 68).

The topoi of the Theresienstadt literature as the fear of being transported to Poland (to the unknown East) are also present in both Weiss' novella and poetry (Weiss, 1998, p. 94). Moreover, František Kafka - as well as Otto Weiss - in his short story $\rightarrow$ A Christmas Legend from the Ghetto, which was written in the Lodz Ghetto in 1941, also used religious motifs. Weiss' sarcastic personification of God definitely questions His omnipotent nature. The helpless God (Emil Knieža’s $\rightarrow$ The Sixth Battalion, On Guard!; Viktor Fischl's $\rightarrow$ Court Jesters), however, does not mean the work can be interpreted as atheistic (Demetz, 2003, p. 32). The narrator is rather searching for an answer about the limits of one's belief and for God's reasons for having to face such 
a tragic situation. This interpretation is supported by the introductory poem called Prayer (Modlitba) which is included in the Czech edition of the prose. However, it is not part of the original manuscript of the English or German editions (Weiss, 2016, pp. 7-8). Moreover, Weiss' original placement of Prayer as the closing piece of his collection of poems How the Stars Were Hurting (which he had already finished and compiled in Theresienstadt; Weiss, 1998, pp. 112-113), was crucial for expressing Weiss' artistically faithful attitude towards God. Its placement in the collection of poems expresses no sarcasm, seemingly in contrast to its placement to the Czech edition of the novella (by his daughter) in 2016.

\section{Cited Works}

Badinová, A. (2016). "Pohádka” z Terezína. Klub knihomolů [online]. 16. 12. Available at: http://www.klubknihomolu.cz/135491/pohadka-z-terezina/ [Accessed: 03.12. 2020]. Balík, Š., Holý, J. (2016). Mezi tichem a křikem: Poezie o šoa. In: J. Holý, ed., Cizí i blízcí: Židé, literatura, kultura v českých zemích ve 20. století. Praha: Akropolis, pp. 431-520. Bondy, R. (2010). Afterword. The Terezín Ghetto - Matter of Perspective. In: O. Weiss, And God Saw That It Was Bad. Jerusalem: Yad Vashem, pp. 73-78. Demetz, P. (2003). Mit Pappkoffer, doch ohne Licht. Otto Weiss schickt Gott als irdischen Zivilisten nach Theresienstadt. Frankfurter Allgemeine Zeitung, 10.7., (157), p. 32. Munk, J. (2004). Theresienstadt in Bildern und Reimen, ed. E. R. Wiehn. Konstanz: Hartung-Gorre. Sabin, S. (2002). Nachwort. Der ohnmächtige Gott. In: O. Weiss, Und Gott sah, dass es schlecht war. Göttingen: Wallstein, pp. 57-60. Weiss, O. (1998). Tak bolely hvězdy. Praha: Sefer. Weiss, O. (2002). Und Gott sah, dass es schlecht war. Göttingen: Wallstein. Weiss, O. (2010). And God Saw That It Was Bad. Jerusalem: Yad Vashem. Weiss, O. (2016). I viděl Bůh, že je to špatné. Brno: Jota.Wittemann, M. T. (2004). Helga Weissová: Zeichne, was du siehst! Stifter Jahrbuch, 18, pp. 212-219.

\section{Further References}

Frantinová, E. (2017). I bůh to viděl. Haló noviny. 3. 5., 27(102), p. 2. Literatura Umění - Kultura 18. Available at: http://www.obrys-kmen.cz/index.php/rocnik2017/171-18-2017-3-kvetna-2017/1753-i-buh-to-videl [Accessed: 02.11.2019]. Hošková-

Weissová, H. (2016). Doslov. In: O. Weiss, I viděl Bůh, že je to špatné. Brno: Jota, pp. 103-105. 